\title{
Conflict Management Strategies in Ondo State Tertiary Institutions
}

\author{
Dr. Dorcas Oluremi Fareo \\ Dr. Mohamed Alison Jajua
}

Department of Science Education, Faculty of Education, Adamawa State University, Mubi, Nigeria

Doi: 10.19044/esj.2018.v14n4p315 URL:http://dx.doi.org/10.19044/esj.2018.v14n4p315

\begin{abstract}
This paper investigated conflict management strategies in tertiary institutions in Ondo State. As a descriptive survey, the study population comprised all the staff and the management of three institutions. For the study sample, two hundred and ten was selected by stratified sampling technique. The instrument for data collection was 45 items Likert-type questionnaire tagged 'Conflict Management Strategies Questionnaire' (CMSQ). The reliability of the instrument was determined through test-retest method and the reliability co-efficient was 0.86 . The content and face validity of the instrument was carried out by one expert in Test and Measurement, an expert in Psychology of Education; and an expert in Guidance and Counselling. The data collected were analyzed using frequency count, percentages, Analysis of Variance (ANOVA), and Multiple Regression. It was found that conflict in Federal University of Technology (FUTA), Rufus Giwa Polytechnic and Adeyemi College of Education occurred frequently. Nonpayment of salaries as at when due was the major cause of conflict in these institutions. The most effective conflict management strategies used was participatory decision strategy. Based on the findings, it was ascertained that role conflict occurred between academic staff and professional administrators; and conflict management strategies were critical variables in the school system. It was recommended that the academic and professional administrators should continue to demonstrate spirit of tolerance so as to ensure the smooth running of university, polytechnic and the college.
\end{abstract}

Keywords: Conflict; strategies; administrators; academics; theory; management 


\section{Introduction}

Conflict is when two or more values, perspectives and opinions are contradictory in nature and have not been aligned or agreed to, including: within oneself when one is not living according to one's values; when values and perspectives are threatened; or discomfort from fear of the unknown or from lack of fulfillment. Conflict is inevitable and often good, for example, good teams always go through a "form, storm, norm and perform" period. Getting the most out of diversity means contradictory values, perspectives and opinions (McNamara, 2007). Many people view conflict as an activity that is almost totally negative and has no redeeming qualities. Some consider it as dysfunctional, destructive, and the same time as a catalyst for change, creativity and production (Posigha \& Oghuvwu, 2009). The college and organizations is not immune from conflict. This is because; in any circumstances where two or more people co-exist to form an organization, conflict is anticipated.

The university and college systems comprise a variety of communities based on the wide range of academic disciplines and functions. Its internal behaviour constitutes a very complex organism shaped by many hands. This implies that, internally the university or college life is shaped by many logic, habits and dynamics. It is also influenced by various challenges, constraints and pressures from the outer environment. The combinations of external pressures and internal pressures within the university and college systems made administration very difficult and complex, therefore conflict is inevitable. Conflicts have given rise to distrust and hostility among professionals and academics, thus contributing in hampering smooth, effective and efficient administration in the universities. It also appears that despite this situation, stakeholders in education seem to develop non-challant attitude towards conflicts. If this role conflict is not checked, it can be descriptive and negative as people involved will often see one another as enemy. This is unwholesome for the college community and Nigeria educational system as a whole ( Ndum \& Okey (2013). De Janasz, Dowd, and Schneider (2006) stressed that conflict is a fact of life in organizations.

According to Folgers and Shubert (1995), colleges and universities are no longer seen as quiet enclaves free from the conflicts that arise in all hierarchical organization. Differences in goals or plans for the allocation of resources, misinterpretation or inconsistent application of institutional regulations, breaches of formal or informal contracts, power struggles and personal antagonisms are all possible sources of conflict. Many scholars suggest that conflict can both be constructive and destructive, Constructive conflict is known as functional conflict while destructive conflict is known as dysfunctional conflict. Functional conflict is defined as challenging of ideas, beliefs, and assumptions, and respect for others' viewpoints even when parties 
disagree (Massey \& Dawes; 2007). It is considered useful for the organization and is therefore welcomed, while dysfunctional conflict is considered damaging and is therefore discouraged in the organizations. Dysfunctional conflict is thought to increase dissatisfaction and decrease the affective wellbeing of the employees and decline the organizational efficacy (Rahim, 2000; Guerra et al., 2005).

\section{Theoretical Framework}

The study is hinged on Process Theory proposed by Goldman (1966), in Alade (1998). The theory states that the observation of conflicts pertaining to major organizational offices is a reliable procedure for sampling the developmental tendencies of the organization as a whole. Therefore when universities experience positive/non-destructive role conflicts, innovations and creativity would emerge, which will further lead to better conflict resolutions and conflict avoidance; thus improving the administrators' effectiveness and efficiency in accomplishing set goals and objectives of the universities. Another theory that lends credence to this study is the StructuralFunctional Theory propounded by Pearson (1960) in Alade (1998). The theory postulates that individuals normally adjust to a given structure in an organization; however, any change in the structure of the organization causes conflict and destabilizes the organization. Conflict should be minimized by minimizing structural changes in order to maintain stability with both the individuals as well as the institutions.

\section{Empirical Studies}

A number of research findings showed that various form of conflicts also occur at varying degrees and proportions in colleges and universities. Amuseghan (2007) for instance, found that the level of occurrence of studentauthority conflicts in the United Kingdom (UK) and Canadian universities was high, while Oyebade (2000); Awosusi (2005); Adeyemi, 2009; Adeyemi and Ademilua (2012) and Olaleye and Arogundade (2013) studies revealed that the occurrence of conflict in Nigerian colleges of education and universities were at a frequent level. Their studies also highlighted that communication gap between management and workers were the leading cause of conflict in the universities. Oyebade (1994) in another study described conflict as inevitable. Conflict can therefore be described as a fact of life, and it can be said to be a reality in any social system. In the Nigerian institutions, there had been chains of conflicts which had led to gradual but steady disruption of academic activities.

Many scholars have identified different conflict management strategies being used in organizations. Oyebade, (2000); Adeyemi (2010); Adeyemi and Olumilua (2012); and Olaleye and Arogundade (2013) revealed 
in their studies that the most effective strategies for resolving conflict was through dialogue between the two parties involved. The strategy identified by Meyer (1994) was effective communication which he described as the best because it would make the group aware of the kind of communication which could lead to problem solving. Nevertheless, Ibukun (1997) identified problem solving, appeal to superior organizational goals, prevention and avoidance, expression of opportunities and resources, use of authority and command, changing the structure of the organization and compromise as management strategies for resolving conflicts organizations.

Likewise, Oyebade (1995) identified certain strategies as important in resolving conflict. These strategies include dialogue, automatic, emergency and delaying approaches. The efforts of all stakeholders in the college/university management are required in ensuring amicable resolution of conflict. In this regard, Adebayo (2007) postulated that the first strategy of conflict resolution is commitment to the management of productive conflict, such that conflict does not become destructive. He advocated for these strategies by enjoining leaders, management and all in positions of authority to promote the rule of law, protect the fundamental human rights, promote human freedom, fair allocation of values and equity of justice. These values are very essential in order to reduce friction and conflict in organizations. It has been observed that Nigerian colleges and universities have for decades been faced with so many crises ranging from conflict between academic staff and colleges and university administrators, students versus academic staff, students versus college or college management, non-academic staff versus college administrators

\section{Conflicts of Interest in Tertiary Institutions}

Conflicts of interest in tertiary institutions are as follows:

i. students versus college/university management on issues of increase in tuition fees, poor electricity and water supply, attaching death of students to bad administration of the Provost/ Vice-Chancellor of the college, polytechnic or university. This conflict degenerated in Adeyemi College of Education to destruction of property which led to the closure of the institution for ten months in 2012.

ii. Students versus lecturers: Students attributing their poor performances to lecturers' weaknesses or wickedness.

iii. Staff versus the Provost/Vice-Chancellor: delay in salary payment, lack of promotion when due, delay of promotion areas,

iv. Staff versus Federal/State Government: Areas of interest included nonpayment of certain benefits and allowances. In Federal University of Technology, Akure, the non teaching staff went to strike for almost a year in 2016due to certain conflict between the workers and the Vice-Chancellor; 
while both academic and non-teaching staff of Adeyemi College of Education went on strike for six months in 2014 in demand for their rights. This ugly incidence had led to strikes, students' unrests, and closure of schools in many institutions in Nigeria. It was against this backdrop that this study was carried out to examine the causes of conflicts in tertiary institutions and determine the most effective management strategies that could be used in resolving them. In addressing this problem, three research questions and one research hypothesis were postulated.

\section{Research Questions}

1. What is the frequency of occurrence of conflict in Ondo State tertiary institutions?

2. What are the causes of conflict in Ondo State tertiary institutions?

3. What are the effects of conflict in Ondo State tertiary institutions?

4. What are the most commonly used conflict management strategies in Ondo State tertiary institutions?

\section{Method}

This study is a descriptive research design of the survey type. The population was made up of all staff and management of Federal University of Technology (FUTA), Rufus Giwa Polytechnic and Adeyemi College of Education. For the study sample, two hundred and ten was selected by stratified sampling technique. The instrument for data collection was 45 items Likert-type questionnaire tagged Conflict Management Strategies Questionnaire (CMSQ) adapted from Adeyemi and Ademilua (2012); and Olaleye and Arogundade, (2013). Section A of the instrument was on bio-data of the respondents. Section B contained items which elicit information on items relating to frequency of occurrence of different types of conflicts in Ondo State tertiary institutions. Section C consisted of items relating to the major causes of role conflict between professional and academic in Ondo State tertiary institutions. Section D consisted of items relating to effects of conflict between professional administrators and academic and non teaching staff; while Section E consisted of items relating to the most commonly used strategies employed by university/college administrators in managing conflict. The response scale was scored as follows. Strongly Agree, Agree, Disagree and Strongly Disagree.

The reliability of the instrument was determined through the test-retest method. The instrument was administered twice on thirty academic and professional administrators of Obafemi Awolowo University within a time lapse of three weeks. The computed reliability co-efficient was 0.86 . The content and face validity of Conflict Management Strategies Questionnaire "CMSQ" was carried out by one expert in Test and Measurement, an expert 
in Psychology of Education; and an expert in Guidance and Counselling. Appropriate suggestions were made to improve the quality of the questionnaire by deleting the inappropriate question items, and by modifying some.

\section{Data Analysis}

Data were analyzed using frequencies, percentages, mean Standard Deviation and bar charts.

\section{Results}

\section{The frequency of occurrence of conflict in Ondo State tertiary institutions}

To answer this question, data on some question items were extracted from the data collected on Conflict Management Strategies Questionnaire "CMSQ". The data were analyzed using percentages. The results are presented in Table1

Table 1: Frequency of occurrence of the different types of conflict in tertiary institutions in

\begin{tabular}{|c|c|c|c|c|c|c|}
\hline S/N & Items & $\mathrm{N}$ & Freq & $\%$ & Rarely & $\%$ \\
\hline 1 & $\begin{array}{c}\text { Conflict between academic staff and the professional } \\
\text { administrator }\end{array}$ & 200 & 99 & 49.5 & 101 & 50.5 \\
\hline 2 & $\begin{array}{c}\text { Conflict between academic staff and the Government } \\
\text { Conflict between the non-teaching staff and the } \\
\text { professional administrators }\end{array}$ & 200 & 120 & 60 & 80 & 40 \\
\hline 3 & $\begin{array}{c}\text { Conflict between the non-teaching staff and the } \\
\text { college administrator }\end{array}$ & 200 & 90 & 45 & 110 & 55 \\
\hline 4 & $\begin{array}{c}\text { Conflict between the nonteaching staff and the } \\
\text { Government }\end{array}$ & 200 & 81 & 40.5 & 119 & 59.5 \\
\hline 5 & $\begin{array}{c}\text { Conflict between the students and the university } \\
\text { authorities }\end{array}$ & 200 & 67 & 33.5 & 133 & 68.5 \\
\hline 6 & Inter-personal conflicts among staff & 200 & 100 & 50 & 100 & 50 \\
\hline 7 & Inter-personal conflict among students & 200 & 124 & 62 & 76 & 38 \\
\hline 8 & Conflict among academic staff and students & 200 & 84 & 42 & 116 & 58 \\
\hline 9 & Conflict between academic staff union and non- \\
academic staff union & 200 & 44 & 21 & 156 & 78 \\
\hline 10 & Conflict between students and the host community & 200 & 42 & 21 & 158 & 79 \\
\hline 11 & Mean & 200 & 970 & 44 & 1,230 & 56 \\
\hline
\end{tabular}

Ondo State 


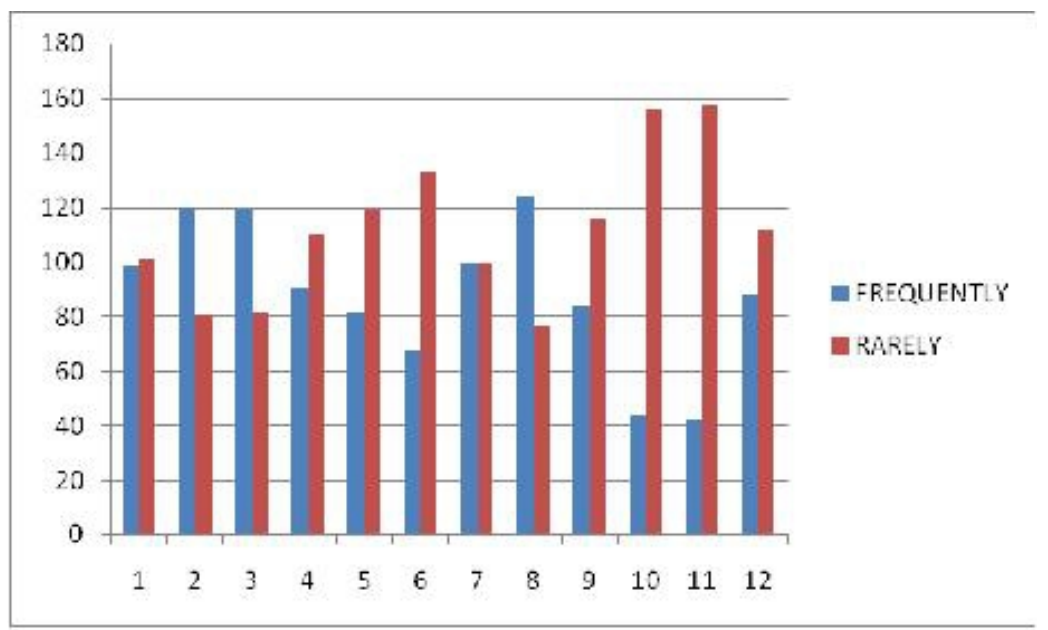

Figure 1: Bar Chart on the Frequency of Occurrence of different types of Conflict in Ondo State tertiary institutions

\section{Key}

1 -Conflict between academic staff and the professional administrator

2 -Conflict between academic staff and the government

3- Conflict between the non-teaching staff and the professional administrator 4 -Conflict between the non-teaching staff and the college/university administrator

5- Conflict between the students and the university authorities

6 -Inter-personal conflicts among staff

7 -Inter-personal conflict among students

8-Conflict among academic staff and students

9- Conflict between academic staff union and non-academic staff union

10 -Conflict between academic staff union and non-academic staff union

11 -Conflict between students and the host community

\section{Causes of conflict in Ondo State tertiary institutions}

To answer this question, data on some question items were extracted from the data collected on Conflict Management Strategies "CMSQ" questionnaire. The data were analyzed using percentages. The results are presented in Table 2

Table 2: Causes of Conflict in Ondo State tertiary institutions

\begin{tabular}{|c|c|c|c|c|c|c|}
\hline S/N & Items & $\mathrm{N}$ & Freq & $\%$ & Rarely & $\%$ \\
\hline 1 & Non-payment of salaries as at when due & 200 & 157 & 78.5 & 43 & 21.5 \\
\hline 2 & Sudden change in university policies & 200 & 120 & 60 & 80 & 40 \\
\hline 3 & $\begin{array}{c}\text { Imposition of decisions on employees by } \\
\text { professional administrators }\end{array}$ & 200 & 121 & 60.5 & 79 & 39.5 \\
\hline 4 & $\begin{array}{c}\text { Inadequate provision of physical amenities such as } \\
\text { electricity and water }\end{array}$ & 200 & 124 & 62 & 76 & 38 \\
\hline 5 & Denial of rights and privileges & 200 & 124 & 62 & 76 & 38 \\
\hline
\end{tabular}




\begin{tabular}{|c|c|c|c|c|c|c|}
\hline 6 & $\begin{array}{c}\text { Non implementation of government circular on staff } \\
\text { welfare }\end{array}$ & 200 & 103 & 51.5 & 97 & 48.5 \\
\hline 7 & $\begin{array}{c}\text { Allegation of corruption against university } \\
\text { professional administrators }\end{array}$ & 200 & 102 & 51 & 98 & 49 \\
\hline 8 & $\begin{array}{c}\text { Communication gap between the authorities and the } \\
\text { workers }\end{array}$ & 200 & 117 & 58.5 & 83 & 41.5 \\
\hline 9 & $\begin{array}{c}\text { Discriminatory application of College/university } \\
\text { rules and regulations }\end{array}$ & 200 & 98 & 49 & 102 & 51 \\
\hline 10 & Improper power assignment & 200 & 81 & 40.5 & 119 & 59.5 \\
\hline 11 & Miscomprehension of duties & 200 & 98 & 49 & 102 & 51 \\
\hline 12 & $\begin{array}{c}\text { Refusal of management to honour agreement reached } \\
\text { with workers union }\end{array}$ & 200 & 116 & 58 & 84 & 42 \\
\hline & Mean & 200 & 1,361 & 56.7 & 1.036 & 43.3 \\
\hline
\end{tabular}

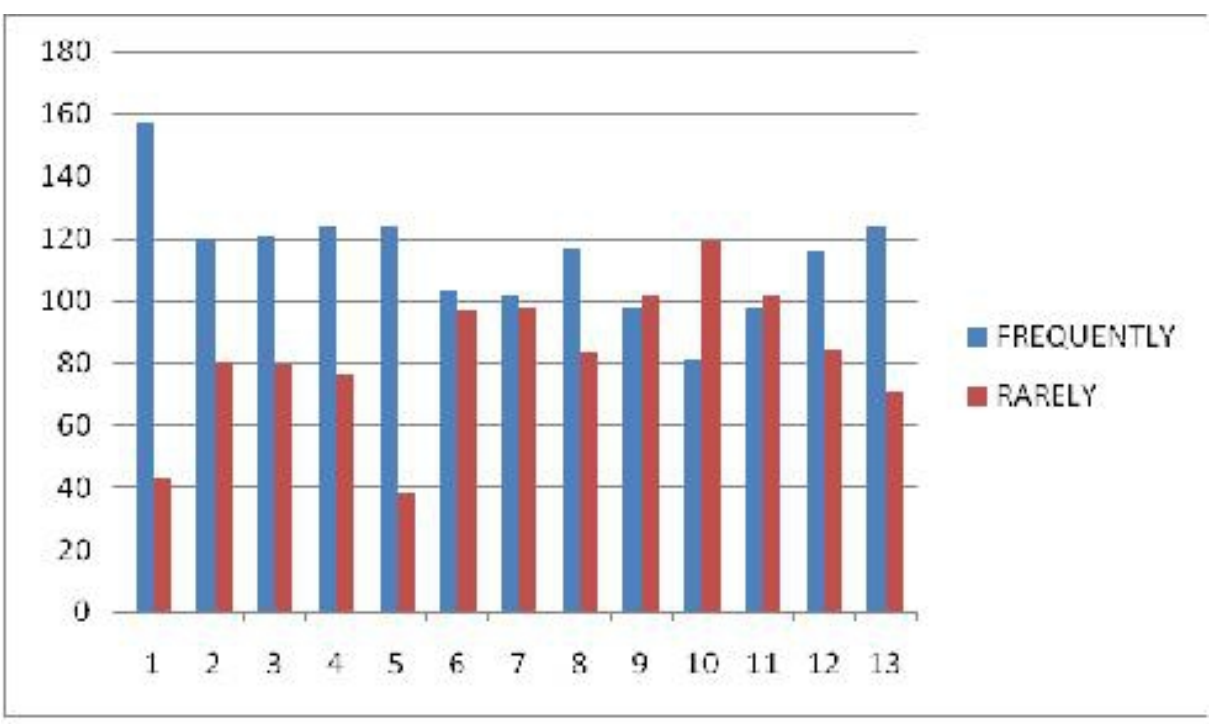

Figure 2: Bar Chart on the Causes of Conflict in Ondo State Tertiary Institutions

Key:

1 - Non-payment of salaries as and when due

2 - Sudden change in university policies

3 - Imposition of decisions on employees by management

4 - Inadequate amenities such as electricity and water

5 - Denial of rights and privileges

6 - Non implementation of government circulars on staff welfare

7 - Corruption allegations against management

8 - Communication gap between the authorities and workers

9 - Discriminatory application of university rules and regulations

10 - Improper power assignment

11- Miscomprehension of duties

12 - Refusal of management to honour agreement reached with workers union 


\section{The effects of conflicts in Ondo State tertiary institutions}

To answer this question, data on some question items were extracted from the data collected on Conflict Management Strategies Questionnaire "CMSQ". The data were analyzed using percentages. The results are presented in Table 3.

Table 3: Effects of Conflict in Ondo State tertiary institutions

\begin{tabular}{|c|c|c|c|c|c|c|}
\hline S/N & Items & $\mathrm{N}$ & Freq & $\%$ & Rarely & $\%$ \\
\hline 1 & Low productivity among staff & 200 & 146 & 73 & 54 & 27 \\
\hline 2 & $\begin{array}{c}\text { Inability to achieve the goals and objectives } \\
\text { of the institution }\end{array}$ & 200 & 140 & 70 & 60 & 30 \\
\hline 3 & Closing down of universities & 200 & 99 & 49.5 & 101 & 50.5 \\
\hline 4 & Loss of lives and properties & 200 & 116 & 58 & 84 & 42 \\
\hline 5 & $\begin{array}{c}\text { Suspension or dismal of staff and students } \\
\text { found guilty }\end{array}$ & 200 & 83 & 41.5 & 117 & 58.5 \\
\hline 6 & Delay in promotion of staff & 200 & 131 & 65.5 & 69 & 34.5 \\
\hline 7 & Delay in promotion of salaries & 200 & 116 & 58 & 84 & 42 \\
\hline 8 & $\begin{array}{c}\text { Disruption of academic calendar in the } \\
\text { universities }\end{array}$ & 200 & 91 & 45.5 & 109 & 54.5 \\
\hline & Mean & 200 & 922 & 57.6 & 678 & 42.4 \\
\hline
\end{tabular}

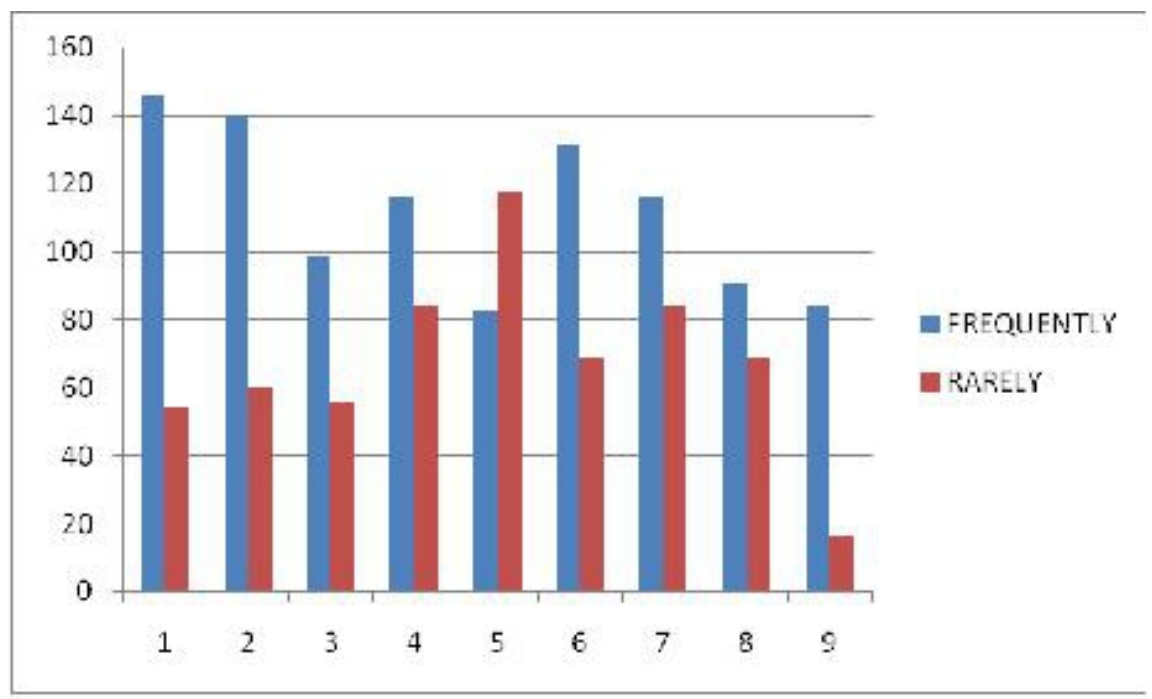

Figure 3: Bar Chart on the Effect of Conflict in Ondo State Tertiary Institutions

Key:

1 - Low productivity among staff

2 - Inability to achieve the goals and objectivities of the institution

3 - Closing down of universities

4 - Loss of lives and properties

5 - Suspension or dismal of staff and students found guilty

6 - Delay in promotion of staff 
7 - Delay in payment of salaries

8 - Disruption of academic calendar in the universities

The most commonly used conflict management strategies in Ondo State tertiary institutions

Table 4: Means and Standard Deviations of the most commonly used Conflict Management Strategies

\begin{tabular}{|c|c|c|c|c|c|c|}
\hline S/N & Conflict Management Strategies & $\mathrm{N}$ & Mean & S. D & Rank & Decision \\
\hline 1 & Force Strategy & 200 & 2.66 & 0.979 & $1^{\text {st }}$ & Accepted \\
\hline 2 & Mediation Strategy & 200 & 2.62 & 0.912 & $2^{\text {nd }}$ & Accepted \\
\hline 3 & Emergency Strategy & 200 & 2.40 & 1.012 & $3^{\text {rd }}$ & Rejected \\
\hline 4 & Ad-Hoc Strategy & 200 & 2.35 & 1.048 & $4^{\text {th }}$ & Rejected \\
\hline 5 & Avoidance Strategy & 200 & 2.30 & 1.066 & $5^{\text {th }}$ & Rejected \\
\hline 6 & Prevention Strategy & 200 & 2.18 & 1.015 & $6^{\text {th }}$ & Rejected \\
\hline 7 & Participation Strategy & 200 & 2.16 & 0.953 & $7^{\text {th }}$ & Rejected \\
\hline 8 & Dialogue & 200 & 1.45 & 0.692 & $8^{\text {th }}$ & Rejected \\
\hline
\end{tabular}

From the results in Table 4, out of the eight conflict management strategies, force strategy rank highest with a mean of 2.66 and Standard Deviation of 0.979. This is followed by Mediation strategy (Mean= 2.62; sd.=0.912).

\section{Discussion}

The study revealed that the occurrences of conflicts in Ondo State tertiary institutions were on frequent level. Foremost among them was conflict between academic staff and the government, while the next to it was conflict between the nonteaching staff and the university/college management. This finding was in line with the study carried out by Olapeju (2003). However, the study disagreed with the findings made by Adeyemi and Ademilua (2012); and Olaleye and Arogundade (2013) which revealed that the conflict between the academic staff and the management as the one having the highest number of respondents.

The findings of the study highlighted the causes of conflicts in Ondo State tertiary institutions according to the order of frequency as nonpayment of salaries as at when due; inadequate amenities such as electricity and water; imposition of decisions on employees by management; denial of rights and privilege; refusal of management to honour agreement reached with workers union; sudden change in the college policy; non implementation of government circulars on staff welfare; communication gap between the management and workers; corruption allegations against management; improper power assignment; discriminatory application of college rules and regulations; and miscomprehension of duties. The study agreed with the 
studies of Adeyemi (2010); Adeyemi and Ademilua (2012); and Olaleye and Arogundade (2013).

The findings of the study revealed that the consequences of conflict in Ondo State tertiary institutions were low productivity among staff; delay in promotion; suspension or dismissal of staff and students found guilty; closing down of school; disruption of academic calendar in the college/university; loss of lives and property; and inability to achieve the goals and objectives of the institution. The findings supported the findings of the study by Olaleye and Arogundade (2013).

\section{Conclusion}

The study revealed that the occurrences of conflicts in Ondo State tertiary institutions were on frequent level. Foremost among them was conflict between academic staff and the government, while the next to it was conflict between the nonteaching staff and the university/college management. Nonpayment of salaries as at when due was the major cause of conflict in these institutions. In addition, role conflict occurred between academic staff and professional administrators in Ondo State tertiary institutions. The most effective conflict management strategies used was participatory decision strategy. Infact, conflict management strategies are critical variables in administrative effectiveness in the school system.

\section{Recommendations}

$>\quad$ University/Polytechnic/College constitution, laws and regulations should be made available to both academic and professional administrators and all staff so as to avoid communication gap and conflict within the system. $>\quad$ The academic and professional administrators should continue to demonstrate spirit of tolerance so as to ensure the smooth running of the college.

$>\quad$ The management of universities, polytechnics and colleges of education should always explore the dialogue strategy as a foremost step in managing conflict before embarking on the others for higher administrative effectiveness in the institutions

$>\quad$ Conflict management should not be seen to connote a rigid approach that suits all situations, rather, it should involve a series of concerted efforts to prevent and arrest a seemingly serious crisis.

$>\quad$ Conditions that promote effective conflict management should include consideration of a wide range of alternative solutions, a cooperative climate, an organized and orderly process, and avoidance of artificial conflict-reducing devices such as voting or relying on a leader to make the final decision. 


\section{References:}

1. Adebayo FA (2001). School climate and students' academic performance in secondary schools.

2. Unpublished PhD Thesis, College of Ado Ekiti, Ado Ekit, 45-87.

3. Adeyemi, T.O. (2009). Causes, consequences and control of students' crises in public and private universities in Nigeria. Educational Research and Reviews, 4 (4).

4. Adeyemi, T.O. (2010). Principals' management of conflicts in public secondary schools in Ondo State, Nigeria: A critical survey. African Journal of Interdisciplinary Studies.

5. Adeyemi, T.O \& Ademilua, S. O. (2012). Conflict management strategies and administrative effectiveness in Nigerian universities. Journal of Emerging Trends in Educational Research and Policy Studies, 3 (3), 368-375.

6. Agbonna, S.A; Yusuf; A \& Onifade, A. B. (2009). Communication and conflict manager's personality in school security and conflict management. Being a text of Paper presented at the 25th Annual National Conference of the Social Studies Association of Nigeria, Held at

7. Michael Otedola College of Primary Education, Noforija, Epe, Lagos State, from 17th - 20th November.

8. Amuseghan, S.A. (2007). Peace and conflict studies: An introductory text. Akure: Stebak Books and Publishers

9. Awosusi, O.O. (2005): Relationship between work alienation and industrial conflicts - A study of academic staff of universities in the South-West Nigeria. Unpublished Ph. D Thesis, College of Ado-Ekiti, Nigeria.

10. De Janasz, S. C., Dowd, K. O. \& Schneider, B. Z. (2006). Interpersonal skills in organizations (2nd Ed.). New York: McGrawHill/Irwin

11. Folgers, J., \& Shubert, J.J. (1995). Resolving student-initiated grievances in higher education: Dispute resolution procedures in a non-adversarial setting. National Institute for Dispute Resolution Report, no. 3. National Institute for Dispute Resolution.

12. Goldman 1966 in Alade, O.A. (1998). Conflict management within the Nigerian Baptist Convention 1984-1994. Unpublished Ph.D. Thesis, College of Ibadan.

13. Guerra, J. M., Martinez, I., Munduate, L., \& Medina, F. J. (2005). A contingency perspective on the study of the consequences of conflict types: The role of organizational culture.

14. European Journal of Work and Organizational Psychology 14(2), 157176. 
15. Ibukun, W. O. (1997). Educational management: Theory and practice. Bamigboye \& Co.

16. Magagula, C.M. (2007). Conflict resolution and management: The role of African higher education institutions. Paper presented at a seminar celebrating the African college day at the College of Swaziland, Kwaluseni. 15th November.

17. Massey, G.R., and Dawes, P.L. (2007). The antecedents and consequences of functional and dysfunctional conflict between marketing managers and sales managers. Industrial Marketing Management, 36, 1118- 1129.

18. McNamara C (2007). Basics of conflict management. Adapted from the Field Guide to Leadership and Supervision.

19. Meyer, J. (1994): A conflict management unit. Paper Presented at the Annual Meeting of the General State Communication Association, Oklahoma City, USA.

20. Ndum, V. M. \& Okey, S. (2012). Conflict management in the Nigerian college system. Journal of Educational and Social Research,3(8),1723.

21. Olaleye,F.O. \& Arogundade, B. B.(2013).Conflict management strategies of college administrators in South-West Nigeria. Kuwait Chapter of Arabian Journal of Business and Management Review, 2 (6), 96-104.

22. Olapeju, O.O (2003): Towards Ensuring Stability of Academic Calendar in Tertiary Institutions in Nigeria: A paper delivered at the National College Stakeholders Consultative Forum held in Abuja on $31^{\text {st }}$ March,

23. Olutade. A.O. (2005). The committee system in the administration of some federal universities in South-Western Nigeria. Unpublished Ph.D. Thesis, College of Ibadan.

24. Oyebade, E.F. (1994): Operations of the Academic Affairs Division A foreign experience. Paper presented at the ANUPA, Federal College of Technology, Akure.

25. Oyebade, E.F. (1995): The relationship between principals' supervisory styles and staff motivation as perceived by teachers in the teacher training colleges of Ondo State. M.Ed Thesis, Department of Educational Administration and Foundations, College of Benin.

26. Oyebade, E.F (2000): Staff-authority conflict and management strategies in the institutions of higher learning in Ondo and Ekiti States. Unpublished Ph.D Thesis, Department of Educational Foundations and Management, College of Ado - Ekiti. 
27. Persons (1960) in Alade O.A. (1998). Conflicts management within the Nigerian Baptist Convention 1984-1994. Unpublished Ph.D. Thesis, College of Ibadan, Ibadan.

28. Posigha, B.E \& Oghuvwu, V. (2009). Conflict among library staff in Bayelsa and Delta State of Nigeria. International Journal of Labour and Organizational Psychology, 3 (1\&2).

29. Rahim, M. A. (2000). Managing conflict in organizations, Westport, CT, USA: Greenwood Publishing Group, Incorporated. 